\title{
Studies on a Diabetic (KK) Strain of the Mouse
}

\author{
Mutsuo Nakamera and Kazuyori Yamada
}

\author{
Department of Anatomy, Nagoya University School of Medicine
}

\begin{abstract}
Summary. This review demonstrates the following points : 1. By glucose tolerance test and the determination of non-fasting blood sugar values, mice of $\mathrm{KK}$ strain (a Japanese strain) have been shown to be in a diabetic state. 2. KK mice have greater than normal body weights, and moderate obesity. 3. Pancreatic insulin activity and adenohypophyseal growth hormone content of KK mice are greater than those of C75BL mice. 4 . The pancreas of KK mice presents many striking changes, such as the hypertrophy and hyperplasia of the islets, the hypertrophy and degranulation of $B$ cells, the abundance of $B$ cell ribosomes and endoplasmic reticulum, the enlargement of the Golgi areas of B cells, and the diminution of the zine content of insular cells. 5. In other organs (eg. adenohypophysis, liver, adrenal and parathyroid) of $\mathrm{KK}$ mice, many changes are also observed. The above features of KK mice are discussed in relation to the presumed metabolic disorder in the mice.
\end{abstract}

Etudes d'une souche diabétique $(K K)$ de souris.

Résumé. 1. Un état diabétique est démontré chez des souris d'une souche japonaise, la souche KK, mis en évidence par une élévation du sucre sanguin et par une diminution de la tolérance au glucose. 2. Le poids corporel des souris KK dépasse la normale; il s'agit d'une obésité modérée. 3. L'activité insulinique du pancréas et le contenu en hormone de croissance de l'hypophyse de souris KK dépassent ceux observés chez des souris C57BL. 4. Histologiquement, on trouve chez les souris KK une hypertrophie et une hyperplasie des îlots de Langerhans, une hypertrophie et une dégranulation des cellules $B$, une abondance de ribosomes et de réticulum endoplasmique des cellules $\mathbf{B}$, un développement marqué de la région de Golgi des mêmes cellules, et une diminution du contenu en zinc des cellules insulaires. D'autres anomalies ont également été observées dans d'autres organes des souris KK, plus particulièrement pour l'hypophyse, le foie, les surrénales et la parathyroïde.

Untersuchungen beim diabetischen $(K K)$ Mäusestamm. Zusammenfassung. 1. Bei Mäusen des KK-Stammes (japanische Zucht) ist mit Bestimmung von Glucosetoleranz und Blutzuckerwerten ein diabetischer Zustand. nachweisbar. 2. Das Körpergewicht von KK-Mäusen liegt über der Norm, und es besteht eine leichte Fettsucht. 3. Die Insulinaktivität des Pankreas und der Gehalt der Hypophyse an Wachstumshormon sind bei KK-Mäusen höher als bei C57BL-Mäusen. 4. Das Pankreas der KKMäuse zeigt auffallende Veränderungen, wie Hypertrophie und Degranulierung der $\beta$-Zellen, reichlich Ribosomen und endoplasmatisches Reticulum in den $\beta$-Zellen, sowie starke Ausbildung des Golgiapparates und Verminderung des Zinkgehaltes der Inselzellen. 5. Auch andere Organe (z.B. Adenohypophyse, Leber, Nebenniere und Nebenschilddrüse) der KK-Mäuse weisen Veränderungen auf.

Key-words: Spontaneous Diabetes, KK mice, Japanese mice, Obesity, Growth hormone, Pituitary, Islets of Langerhans, Pancreas, Ultrastructure, Beta cells, Insulin in pancreas, Sex and diabetes, Adrenal cortex, Zinc.
Koxpo and his associates (1957) established many mouse strains from Japanese native mice. One strain, named KK, was subsequently confirmed by one of us, using biochemical and histological methods, to be of diabetic character (NAK AMURA, 1962). Further studies of this strain of mouse were concerned with the cyto$\log y$ and histochemistry of the pancreatic islets (NAKamura, 1965; NaKamura and Yamada, 1965); parathyroid (YAMADA, 1964); and adenohypophysis (Yamada, Natzamura and YamashtTa, 1966); as well as with the genetics of the diabetic character (NAKAMURA and YAMADA, 1963); and the electrophoretic analysis for the amount of growth hormone of the adenohypophysis (NaKAMURA, 1966). The present paper is a review of the research performed by the authors.

\section{Methods}

In the course of our work on the $\mathrm{KK}$ mice, the following methods were employed.

Blood glucose determination. Blood samples $(0.03 \mathrm{cc})$ were obtained from the tail vein and the blood glucose content was measured by the Hagedorn-Jensen method. Examination of urine glucose. To test for gluco- suria, Tes-Tape (R) (Lilly) was applied to a drop of fresh urine. Estimation of insulin activity. The activity of pancreatic insulin was measured by bioassay. Acid alcohol extracts (BEST, JePHCOTT and ScotT, 1932) from the pooled pancreases of 3 or 4 animals were injected intraperitoneally into fasted $\mathrm{ddN}$ mice (5 mice/pooled sample). Blood sugar values, 1 hour after the injection, were determined, and by comparing these values with those obtained after injection of standard doses of insulin, the insulin content of the pancreas was estimated (averages and standard deviation for 5 test animals).

Electrophoresis of adenohypophyseal extract. The adenohypophyses from 3-4 mice were pooled, homogenized and centrifuged, and the supernatant was electrophoretically examined using acrylamide gel (OGITA, 1965).

Morphological analysis. Pancreases were fixed in Bouin's or Romeis' fluids and 100\% ethanol and treated with a series of techniques such as chromiumhematoxylin and phloxin (C.H.P., GoMorI, 1941), dithizone ammonium (MaEda, FuJiwara and HiroNARI, 1954) and DDD-diazo-blue B with thioglycolate reduction (Barrnett, Marshatil and Seligman, 1955). 
Histochemical methods used for the demonstration of alkaline phosphatase, acid phosphatase, glucose6-phosphatase and ATPase activity were respectively GoMoRI's method (1941), GoMori's method (1950) LAZARUS' (1959) modification of the WACHSTEIYMeiseu method (1956) and Padykula-Herman's method $(1955 \mathrm{a}, \mathrm{b})$.

For light microscopy of the adenohypophysis, tissues were fixed in the chrom-alum fixative (ELFTMAX, 1957) and stained by AF-PAS-orange $G$ procedures. Parallel tissues for electron microscopy were fixed in $1 \%$ buffered osmium tetroxide solution (Palade, 1952), embedded in Epoxy-Epon and stained with uranyl acetate and lead hydroxide. Pancreatic tissues were examined also with the electron microscope.

For the examination of three other organs, liver, adrenal and parathyroid, staining with hematoxylin and eosin (H-E), DDD-diazo-blue B and HNAHdiazo-blue $\mathrm{B}$ were used.

Diet. Animals were maintained on one of the following three diets. a) OA2 diet of CLEA company, Japan. b) Oriental NMF diet of old type (now not sold). c) Boiled corn mixture (Nakamura and Yamada, 1963).

\section{Results}

\section{Body weight data}

Recently, records of the body weights of our KK and C57BL mice have been compiled, in order to corroborate the impression that our KK mice grow faster than other mice. Only males were weighed, because the body weights of females vary greatly with the frequency of pregnancy. The data, given in Table 1 , clearly indicate that individuals belonging to the KK strain are heavier than similarly aged individuals of another strain examined $(P>0.05)$, the difference being statistically significant.

Table 1. Body weights of $K K$ and $C 57 B L$ males of different ages

\begin{tabular}{lll}
\hline \multicolumn{1}{l}{ Ages } & mean wt. in $g . \pm$ s.d. & \\
\cline { 2 - 3 } KK & C57BL \\
\hline $90-149$ days & $33.1 \pm 4.0(19)$ & $26.4 \pm 1.8(17)$ \\
$150-209$ days & $36.0 \pm 4.0(8)$ & $28.5 \pm 1.7(10)$ \\
$210-269$ days & $40.1 \pm 3.0(19)$ & $31.6 \pm 1.7(8)$
\end{tabular}

In addition, it was noted that the KK mice were also characterized by moderate degrees of obesity, which is especially apparent among individuals more than 5 months old.

\section{Glucose tolerance test (NAKAMURA, 1962)}

Glucose tolerance tests were carried out on $28 \mathrm{KK}$ $(o 14, q$ 14) $10 \mathrm{C} 57 \mathrm{BL}(07, q 93)$ and $5 \mathrm{CBA}(02, q 3)$ mice (Fig. 1), the latter two mice varieties serving as control animals. Except for a few individuals, most KK mice showed a lowered glucose tolerance as compared with other strains. When the data are classified according to sex, it is apparent that male KK mice have higher blood sugar eurves than female mice of the same strain (Fig. 2).

\section{Non-fasting blood sugar values}

The distribution of the non-fasting blood sugar values, as listed in Table 2 , is based upon the data

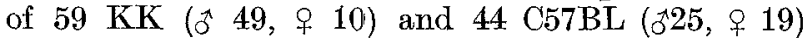
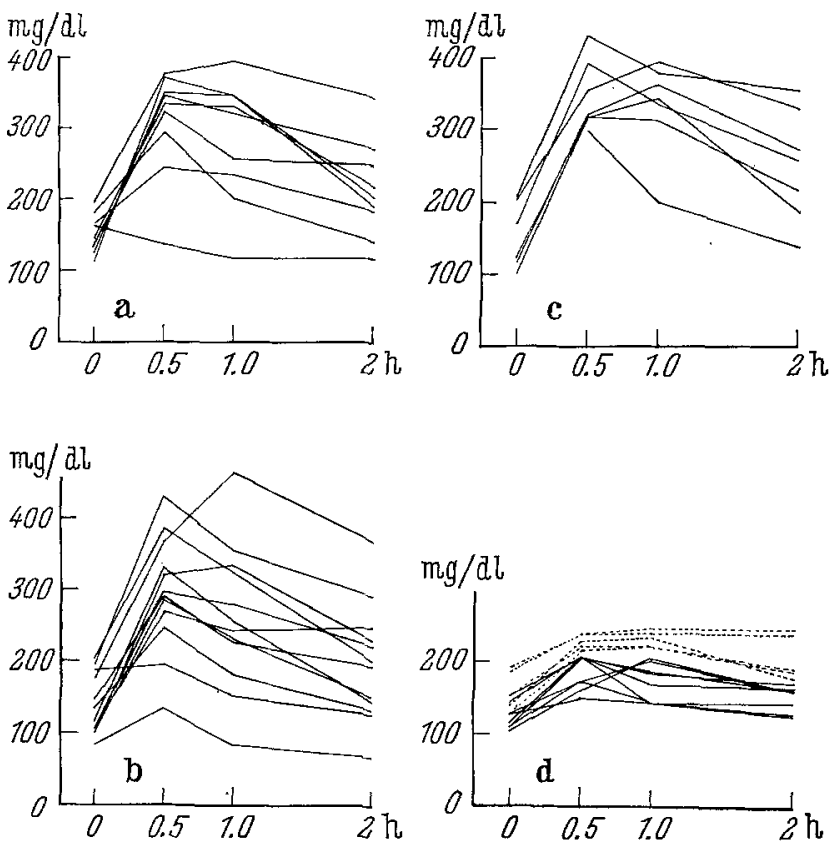

Fig. 1. Blood sugar curves after oral administration of glucose. a) $\mathrm{KK}$ mice below 3 months of age. b) KK mice aged 3 and 4 months. c) KK mice aged 5 months or more. d) C57BL and CBA mice as controls, aged 3,4 and 5 months

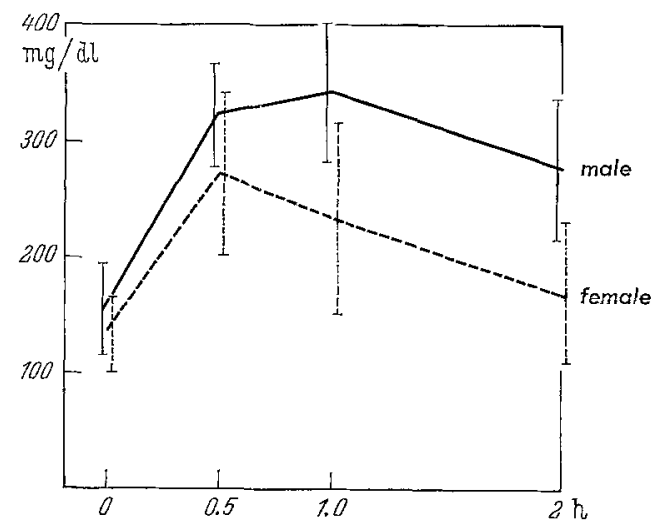

Fig. 2. Mean blood sugar curves of male and female KK Mice

mice randomly selected from our mouse colony. From the table, the following facts are evident. The glycemic values of male KK mice ranged from 120 to $380 \mathrm{mg} / 100 \mathrm{ml}$. Of 49 male $\mathrm{KK}$ mice examined, 23 individuals had blood sugar values equal to or more than $200 \mathrm{mg} / 100 \mathrm{ml}$, and the frequency of such hyperglycemic individuals tends to increase with age. On the other hand, all the female KK mice, except one with a glycemic level of $203 \mathrm{mg}$ / $100 \mathrm{ml}$, had glycemic values below $200 \mathrm{mg} / 100 \mathrm{ml}$. 
In C57BL mice, the blood sugar values are invariably less than $200 \mathrm{mg} / 100 \mathrm{ml}$.

4. The estimation of pancreatic insulin activity (NAKAMURA, 1962)

A total of $13 \mathrm{KK}(57, q 6)$ and $12 \mathrm{C57BL}\left({ }^{*} 6\right.$, ㅇ 3) mice were examined. Pancreases of 3-4 animals were pooled, and bioassay for hormone activity was carried out. The results are indicated in Table 3, which shows that KK mice have a significantly higher insulin activity per gram of pancreatic tissue; in fact, about four times greater than that for C57BL mice.

Table 2. Distribution of the non-fasting blood sugar values of male and female $K K$ mice, and male and female $C 57 B L$ mice

\begin{tabular}{lrrrr}
\hline Strain & \multicolumn{1}{c}{ Age } & \multicolumn{3}{c}{ blood sugar mg/100 ml } \\
\cline { 3 - 5 } & & $<150$ & $150-199$ & $\geqq 200$ \\
\hline Male KK & $90-149$ days & 1 & 16 & 3 \\
& $150-209$ days & & 5 & 7 \\
& $210-269$ days & & 4 & 13 \\
Female KK & $90-149$ days & & 4 & \\
& $150-209$ days & & 2 & \\
Male C57BL & $210-269$ days & & 4 & 1 \\
& $90-149$ days & 1 & 8 & \\
Female C57BL & $150-209$ days & & 16 & \\
& $210-269$ days & & & \\
& $90-149$ days & 4 & 6 & \\
& $150-209$ days & 1 & 8 & \\
& $210-269$ days & & &
\end{tabular}

Table 3. Pancreatic insulin activity of $C 57 B L$ and $K K$ mice

\begin{tabular}{|c|c|c|c|c|c|}
\hline \multirow[b]{2}{*}{ Mice } & \multirow{2}{*}{\multicolumn{2}{|c|}{ Age (months) }} & \multirow[b]{2}{*}{ Giucosuria } & \multicolumn{2}{|c|}{$\begin{array}{l}\text { Estimated insulin } \\
\text { content }\end{array}$} \\
\hline & & & & $\begin{array}{l}\overline{\text { Mean }} \\
\text { (I. U./g) }\end{array}$ & $\begin{array}{l}\text { S.D. } \\
\text { (I.U./g) }\end{array}$ \\
\hline C57BL & 5 & (4 animals) & 一 & 0.7 & 0.23 \\
\hline C57BLô & 5 & (4 animals) & 一 & 0.6 & 0.25 \\
\hline C57BL & 5 & (4 animals) & - & 0.7 & 0.56 \\
\hline KKo & $7-9$ & (4 animals) & ++ & 2.3 & 0.85 \\
\hline KK웅 & 8 & (3 animals) & - & 2.5 & 0.42 \\
\hline $\mathrm{KK}_{\delta}$ & 3 & (3 animals) & $-\sim+$ & 2.2 & 0.50 \\
\hline KK耳우 & 3 & (3 animals) & - & 2.5 & 1.27 \\
\hline
\end{tabular}

5. Electrophoretic analysis of the adenohypophysis (NAKamura, 1966)

By the weighing of adenohypophyses of $7 \mathrm{KK}$ and $7 \mathrm{C57BL}$ mice, it was found that 3 adenohypophyses of $\mathrm{KK}$ mice were nearly equal in weight to 4 corresponding organs of C57BL mice. On the basis of this result, 3 and 4 adenohypophyses were derived repectively from $\mathrm{KK}$ and C57BL mice, pooled together and electrophoretically examined. Animals examined by this method were $15 \mathrm{KK}$ and 20 C57BL males aged 3 months. As far as our observation is concerned, the protein band corresponding to growth hormone (LeWIS, CheEver and VANDERLAAN, 1965) is markedly more intense and broader in $\mathrm{KK}$ mice than in C57BL mice (Fig. 3).

6. Morphological results

a) Pancreatic islets (Nakamura, 1965; Nakamura and YAMADA, 1965). For a histological survey of the pancreatic islet using light microscopy, $28 \mathrm{KK}$ mice $(020$, $q$ 8) ranging in age from 3 to 10 months were used; and 6 C57BL mice $(o 4, q 2)$ aged 3 to 5 months and $9 \mathrm{ddN}$ mice $(\$ 2, q 7)$ aged 3 to 10 months were employed as control animals. In order to correlate morphological data with blood sugar values, blood samples were obtained on killing; and the glucose content of the samples determined.

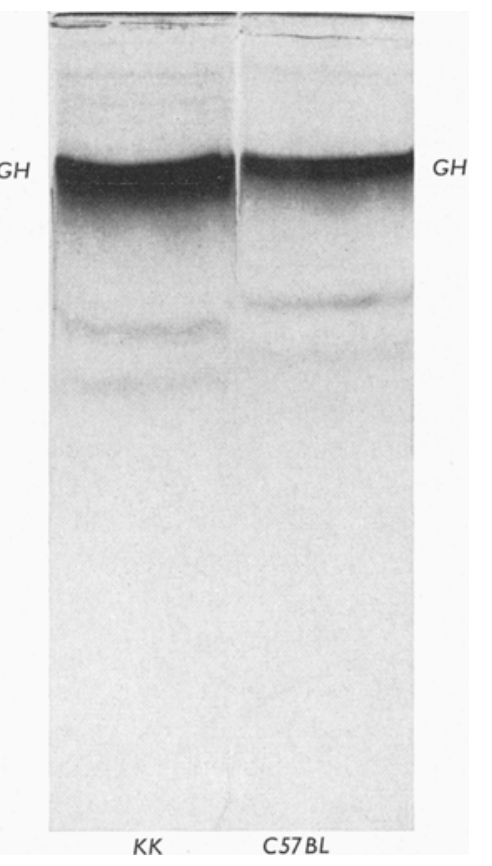

Fig. 3. Electrophoresis of adenohypophyseal extract. GH band is more intense and broader in $\mathrm{KK}$ mice than in $\mathrm{C57BL}$ mice

When pancreatic sections of KK mice were examined under low magnification, one of the striking findings was an alteration in the shape and the size of the islets. In KK mice, islets with elongated or constricted contours occasionally appeared. Furthermore, the hypertrophy and hyperplasia of the islets were evident in some KK mice (Fig. 4). Thus of $21 \mathrm{KK}$ mice with blood sugar values above $200 \mathrm{mg} / 100 \mathrm{ml}$, 10 animals had an obvious enlargement of mean insular size and a concomitant increase in the number of islets compared with control mice. Among the other $7 \mathrm{KK}$ mice with blood sugar values below $200 \mathrm{mg} / 100$ $\mathrm{ml}$, however, only 2 animals exhibited an increase in size and number of islets.

At higher magnifications, it could be seen that the $B$ cells of $K K$ mice had undergone cellular hypertrophy. The nuclei of the cells tended to be ragged in shape, when compared with nuclei of control tissues. The intracellular granules were apparently fewer, colored dark blue and coarser in appearance, making a good contrast to the bright-blue stained, various-sized B cell granules of control mice (Fig. 5 and 6). Furthermore, there is a suggestion that the extent of $B$ cell degranulation in KK mice is correlated with blood sugar levels. 
A cells, which appear in control mice either as clusters at the periphery of the islet or singly in its interior (Fig. 7), are encountered in KK mice only at the islet periphery, and less frequently than in control mice (Fig. 8).

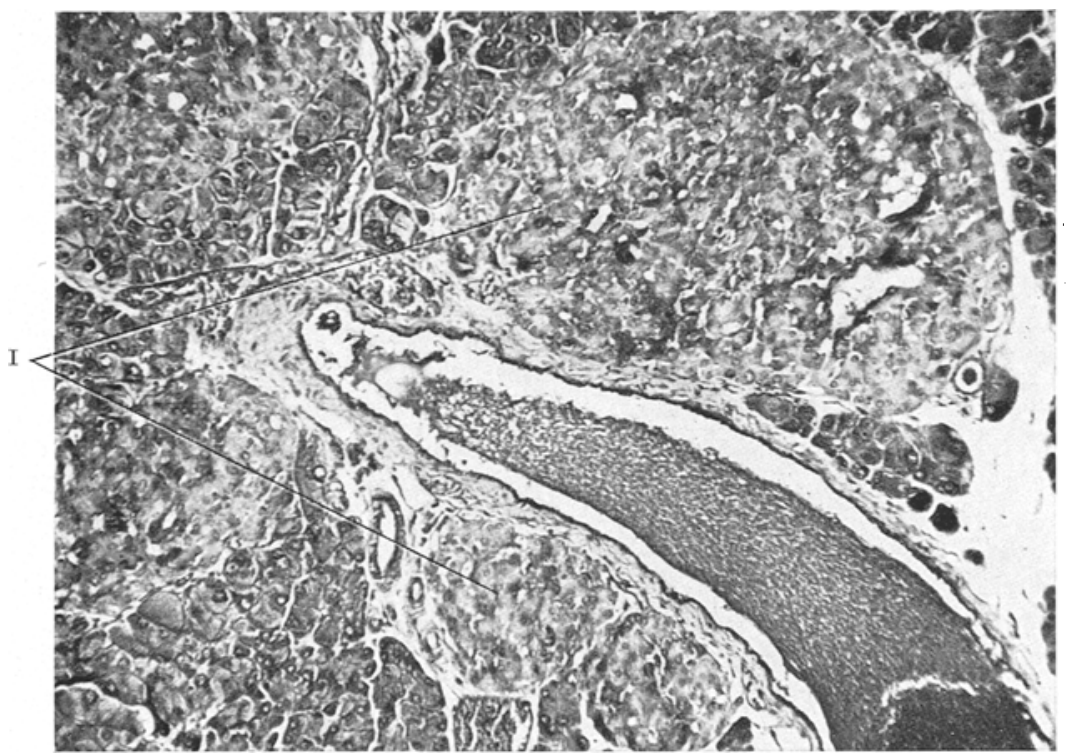

Fig. 4. Pancreas of a KK mouse. Islets (I) are large in size and number. Bouin fixation, C.H.P. stain. $\times 120$

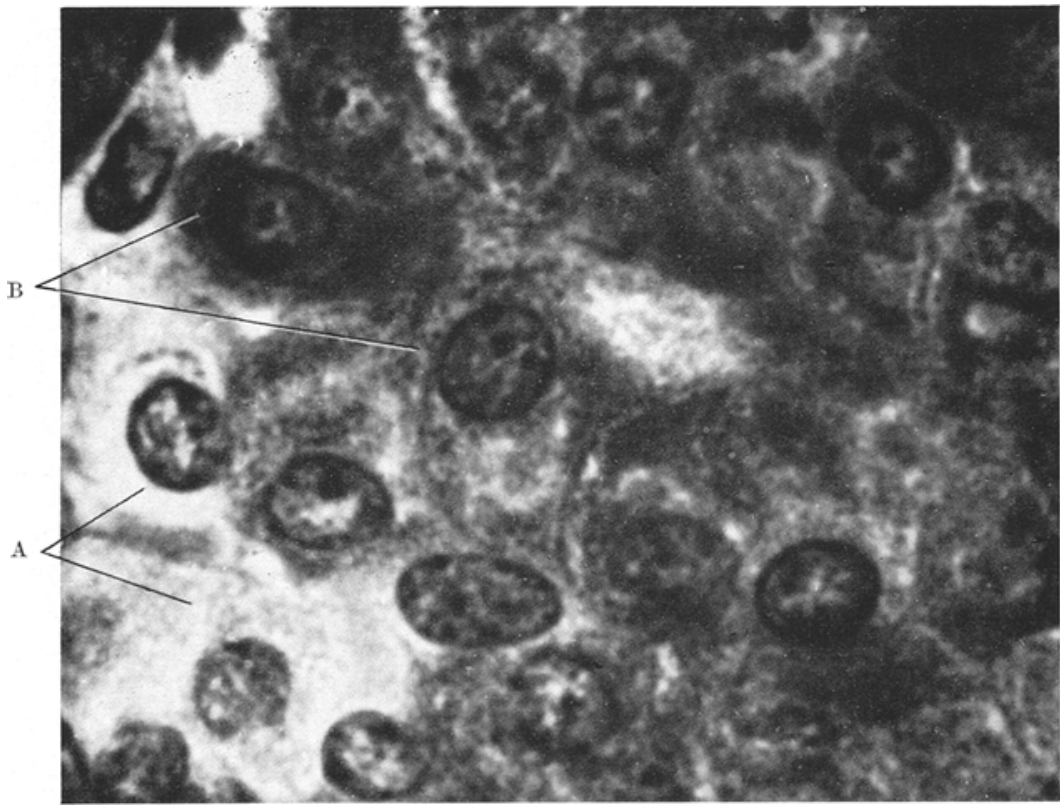

Fig. 5. Pancreatic islet of a C57BL mouse. The cytoplasm of $B$ cells $(B)$ contains bright blue stained granules, and A cells (A) are of finely granular cytoplasm. Bouin fixation, C.H.P. stain. $\times 2000$
According to the dithizone staining method for the demonstration of zinc, the cytoplasm of the insular cells in control animals contains a variable amount of moderately reactive granules (Fig. 9). In contrast to this, the dithizone reaction of the cytoplasm of the islet cells from $\mathrm{KK}$ mice is either feeble or doubtful (Fig. 10). There are no differences in DDD-diazoblue $B$ reactivity between insular cells of both KK and control mice.

In order to study the B cell changes of $\mathrm{KK}$ mice at even finer levels, pancreases of 2 seven month old male KK mice with non-fasting glucosuria were examined under the electron microscope. Corresponding organs from the same number of similarly aged male mice of C57BL strain were also examined. It was confirmed that the B cells of KK mice exhibited cellular hypertrophy, diminution in the number and size of granules, and the existence of a well-developped endoplasmic reticulum and Golgi apparatus as well as an abundance of ribosomes (Fig, 11).

The pancreatic islets of $\mathrm{KK}$ and control (C57BL) mice were also surveyed by histochemical methods for four enzymes: alkaline phosphatase, acid phosphatase, glucose-6phosphatase and ATPase. Animals used in the study consisted of 3 groups, $21 \mathrm{KK}$ mice $(0.17$, 우 4) older than 5 months that had glucosuria, 5 three-month old KK mice $(\delta 3, \circ 2)$ without glucosuria, and 16 C57BL mice $(\hat{o} 10, q 6)$ ranging in age from three to seven months. The following results were obtained:

1. In KK as well as C57BL mice, intense reaction for alkaline phosphatase was found in some peripheral insular cells, and in capillary endothelial cells of the islet, but reactive insular cells in $\mathrm{KK}$ mice occurred less frequently than analogous cells in C57BL mice.

2. In the pancreas of C57BL mice and three-months old KK mice, the cytoplasm of the islet cell reacted

Another characteristic feature of KK mouse islets stained with chromium-hematoxylin phloxin procedures is the existence of a well-developed capillary system within the islets. Especially in KK individuals with islets undergoing extreme hypertrophy and hyperplasia, the capillaries are often sinusoidally dilatated. moderately or weakly positive for acid phosphatase. Older KK mice exhibiting glucosuria revealed a strikingly diminished acid phosphatase activity of the cytoplasm of insular cells.

3. The cytoplasm and nucleus of the insular cells of C57BL mice exhibited moderate and intense reactions for glucose-6-phosphatase respectively. In KK 
mice most insular cells had increased enzyme activity compared with those in C57BL mice.

4. In both C57BL and KK mice, moderate and intense ATPase activities were demonstrated in the insular cells, and in the vascular endothelial cells

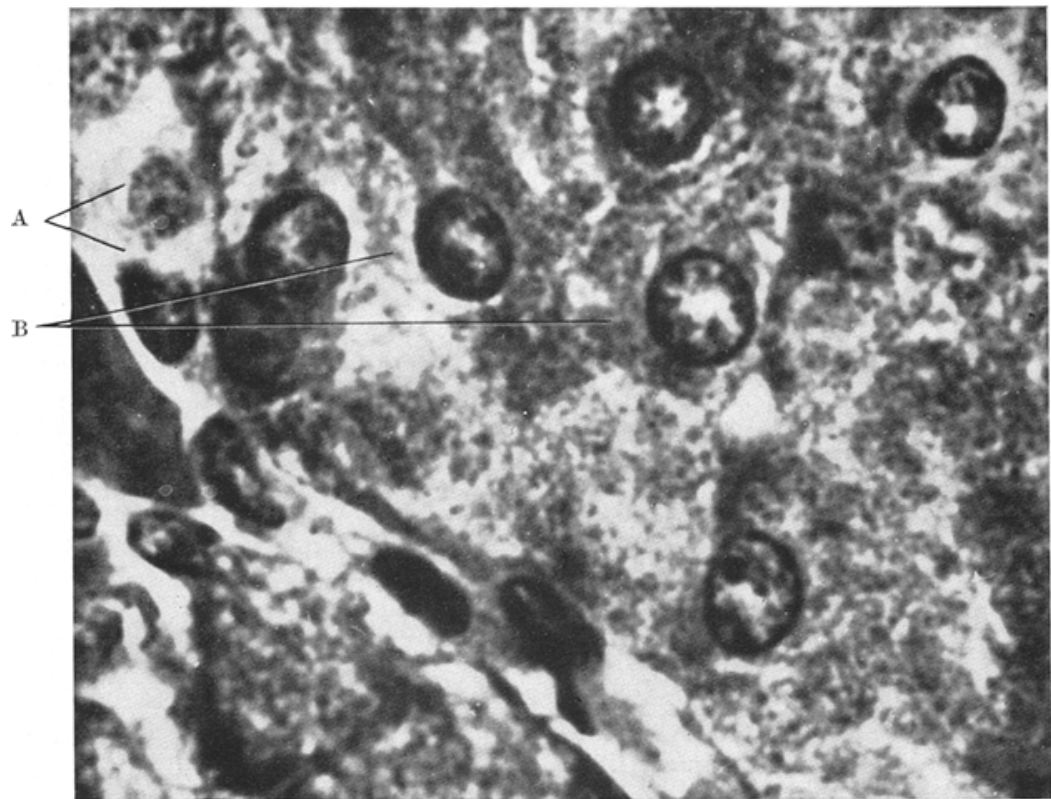

Fig. 6. Pancreatic islet of a $\mathbf{K K}$ mouse. Generally hypertrophied $\mathrm{B}$ cells (B) are provided with nuclei exhibiting a ragged contour and cytoplasm containing a small amount of granules. The cytoplasm of $A$ cells $(A)$ is of fine faintly stained granulation. Bouin fixation, C.H.P. stain. $\times 2000$

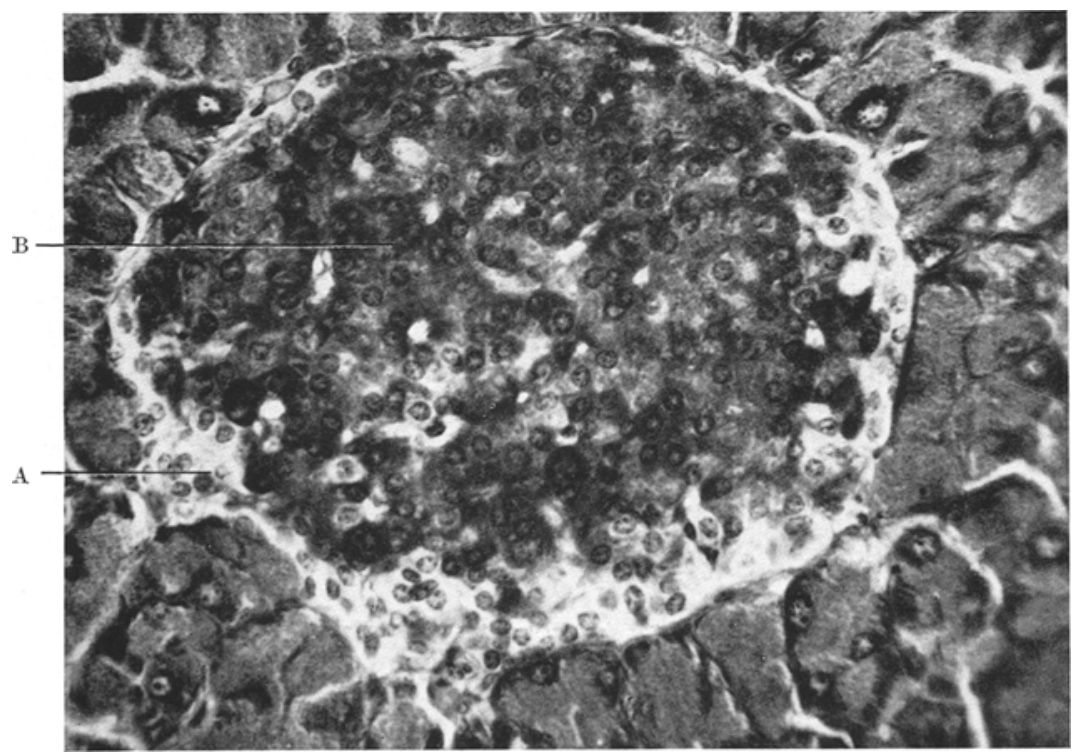

Fig. 7. Pancreatic islet of a C57BL mouse. A cells are found as clusters at islet periphery and singly in its interior. Bouin fixation, C.H.P. stain. $\times 400$

within the islet respectively. The vascular endothelium, as identified by its strong enzymatic activity for ATPase and alkaline phophatase, is more frequently encountered in KK mice than in controls.

b) Adenohypophysis (Yamada, NakaMURA and YaMASHITA, 1966). Anterior pituitaries of 4 three month KK males were examined by light and electron microscopy, the analogous organs of equal numbers of similarly aged C57BL males serving as controls. In KK mice, some cellular hypertrophy and hyperplasia of the $\alpha$ or GH-secreting cell as well as an abundance of secretory granules in the cell was evident (Fig. 12 and 13). Further, $\beta$ or FSH-secreting cells of $\mathrm{KK}$ mice were found to contain more numerous and more distinct granules than the analogous cells of control mice.

c) Other organs. Other organs of KK mice were also examined preliminarily. Only the results concerning liver, adrenal and parthyroid are presented here.

The livers of KK mice with blood sugar values exceeding 240 $\mathrm{mg} / 100 \mathrm{ml}$ showed both a striking decrease in the glycogen content of parenchymal cells, and a deposition of fat; and such changes were either slight or inconspicuous among $\mathrm{KK}$ individuals showing lower blood sugar values.

Morphologic changes found in the adrenal glands of KK mice varied according to sex and age, and were mainly restricted to the cortex of the organ. In male KK mice, the adrenal cortex was diminished in thickness compared with the corresponding organ of C57BL mice (Fig. 14 and 15).

The adrenal cortex of $\mathrm{KK}$ females (especially virgins) was characterized by a narrow zona glomerulosa and fasciculata and by a markedly broad zona reticularis, most cells of which, however, had undergone vacuolization (Fig. 16 and 17). In old males and multipara mice belonging to $\mathrm{KK}$ strain, intense degrees of brown degeneration of cortical cells (Fig. 18) were always found.

In the parathyroid cells of $\mathrm{KK}$ mice the cytoplasm shows stronger reactions for proteins and amino acids with sulfhydryl and carboxyl groups, and RNA and a weaker staining for glycogen than in the cells of ddN mice.

7. Genetic study (NaKaMURA and YaMrada, 1963)

A genetic study performed by us yielded results indicating that the diabetic trait of KK mice may be inherited by multiple genes or polygenes. Since the time is limited, the details of these results are not given here. 


\section{Discussion}

The results of glucose tolerance tests clearly demonstrated that most $\mathrm{KK}$ mice have a lower tolerance for glucose than ordinary mice. The examination of the non-fasting blood sugar values further yielded the finding that about half of male KK mice, aged 5 to

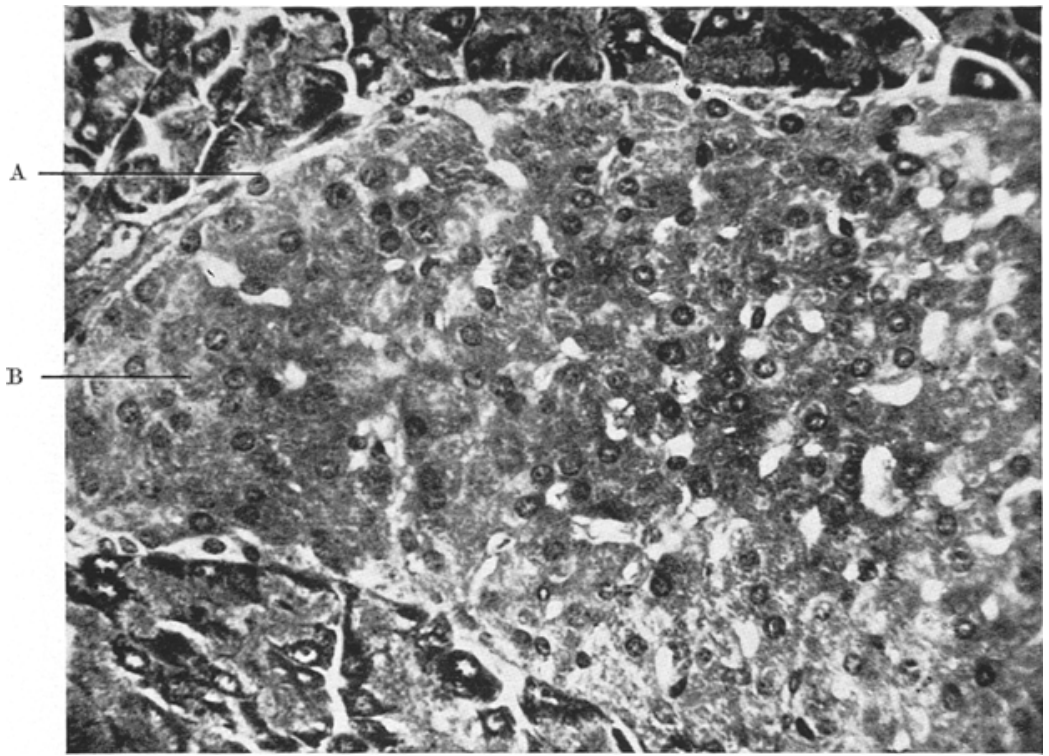

Fig. 8. Pancreatic islet of a KK mouse. A cells are encountered only at the islet periphery and less frequently than in Fig. 7. Bouin fixation, C.H.P. stain. $\times 400$ the diabetic state of these mice is not induced by a primary functional insufficiency of insular B cells, but is due to other endogenous diabetogenic factors. With this hypothesis, the abundance of insulin in the pancreas is seen as the result of the hypersecretion of $B$ cells, a response to the diabetic state.

In the pancreas of $\mathrm{KK}$ mice, many striking changes were observed, such as hypertrophy and hyperplasia of the islets, hypertrophy and degranulation of $B$ cells, abundance of $\mathrm{B}$ cell ribosomes and endoplasmic reticulum, enlargement of the Golgi areas of $B$ cells, and diminution of zinc content of insular cells.

Similar changes were reported in the pancreatic islets of other diabetic strains of mice, e.g. the American obese mouse (WRENSHALL, ANDRUS and MAYER, 1954; BJÖRKMAN, HeLLeRström and HeLLMAN, 1963), the Wellesley obese mouse (Jones, 1964; Like, Steinke, Jones and CAHIL, 1965), the yellow obese mouse (HELLERSTRÖM and HELLMAN, 1963) and the New Zealand obese mouse (BIELschowsky and BIELSCHOWSKY, 1956). When we take into consideration the no-

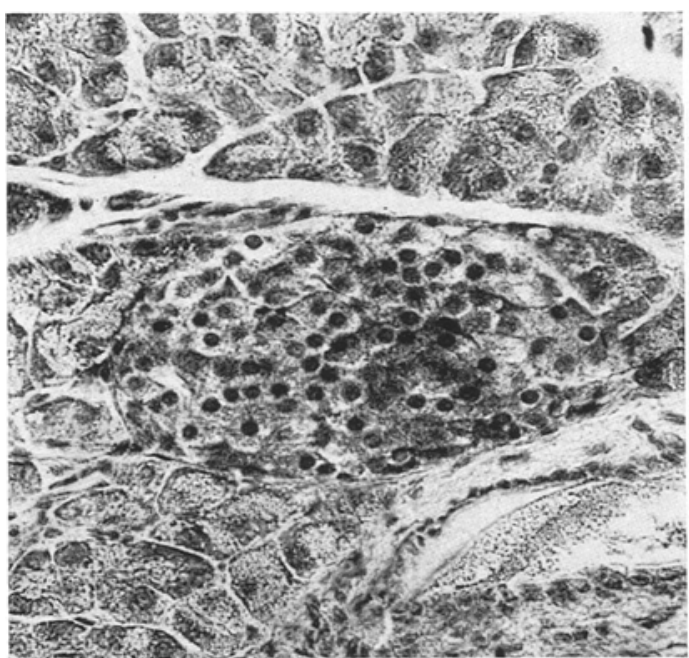

Fig. 9. Pancreatic islet of a C57BL mouse. The cytoplasm of insular cells contains a variable amount of dithizone-reactive granules, $100 \%$. ethano fixation, Dithizone-ammonium stain $\times 300$

8 months, had non-fasting hyperglycemia. It may therefore be concluded that the majority of KK mice are in a diabetic state, although the severity of the condition is subject to a large individual variation.

In spite of the diabetic state, KK mice showed a much higher content of insulin in the pancreas than control mice. The seeming contradiction between diabetic state and high insulin content of the pancreas may be understood in terms of the hypothesis that

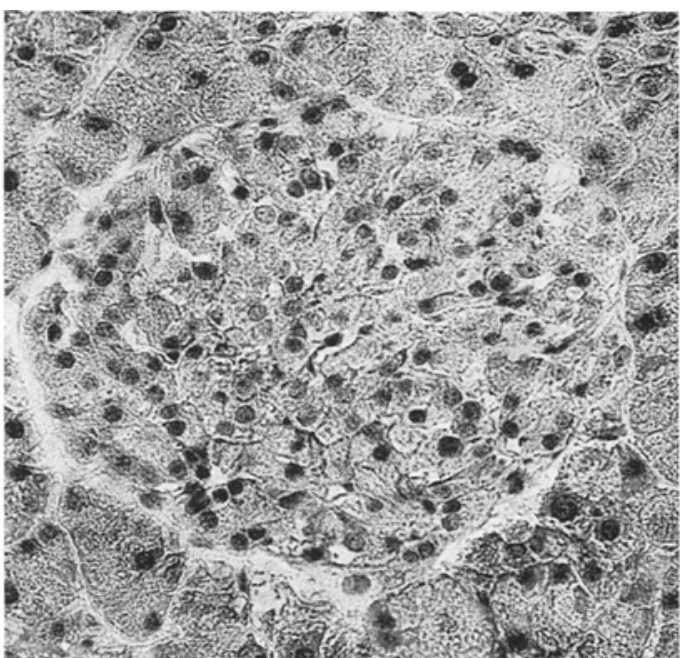

Fig. 10. Pancreatic islet of a $\mathrm{KK}$ mouse. The dithizone reaction of the cytoplasm of the insular cells is either feeble or doubtful. $100 \%$ ethanol fixation, Dithizone-ammonium stain. $\times 300$

tion of LAzAROW and his associates (LAZARow, BAUER and LrNDaLL, 1964) that insulin is synthesized in the microsomes, then appears in the secretory granules, and finally is released outside the $B$ cell, and also Maske's theory (1955) that zinc renders insulin insoluble within the cytoplasm, the above changes in the islets of KK mice can be regarded as histological evidence for the accelerated synthesis and release, as well as the decreased storage, of insulin 


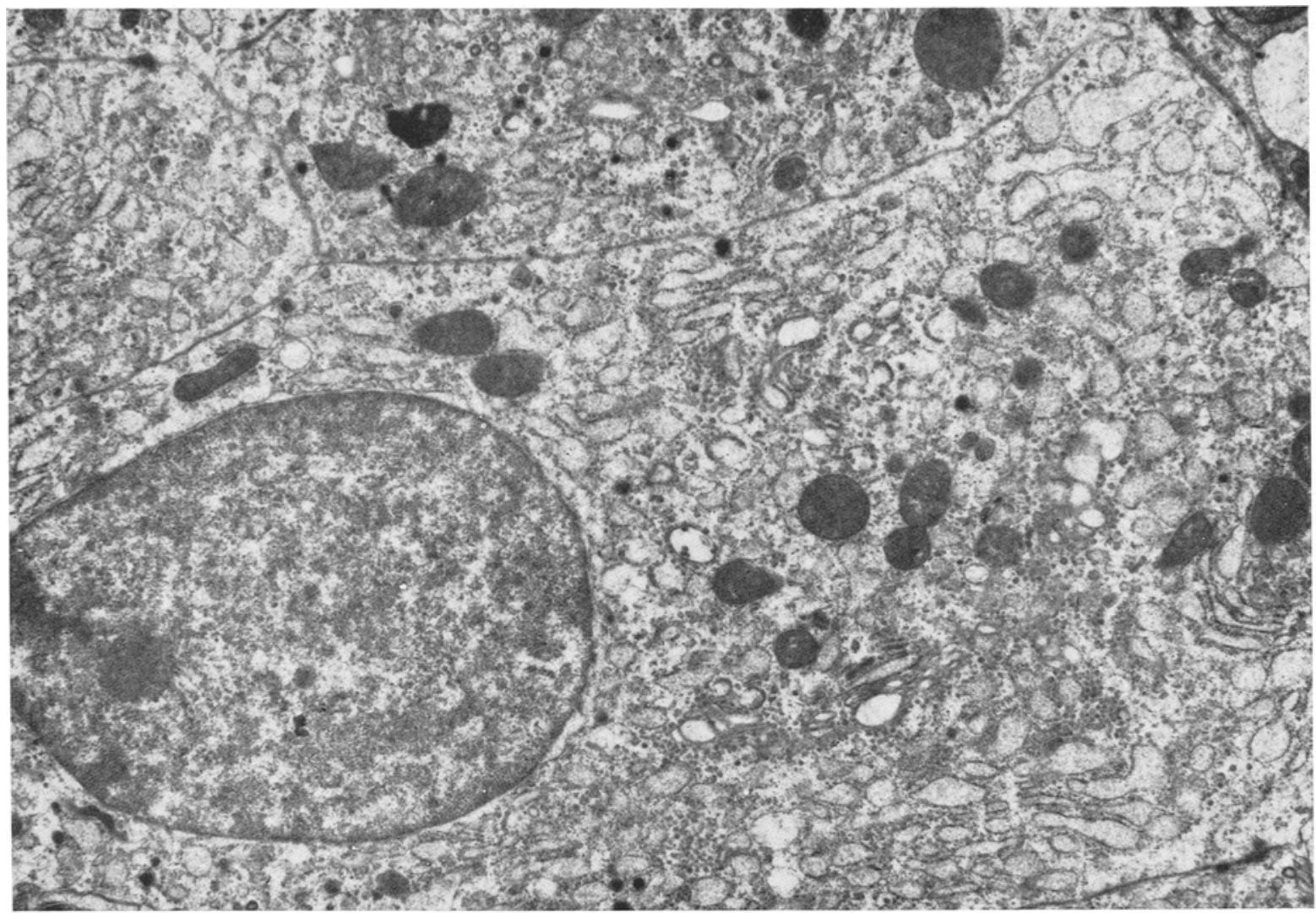

Fig. 11. Electron micrograph of an insular B cell of a KK mouse. An abundance of endoplasmic reticulum and ribosomes, the enlargement of Golgi area and degranulation are apparent. $\times 6000$

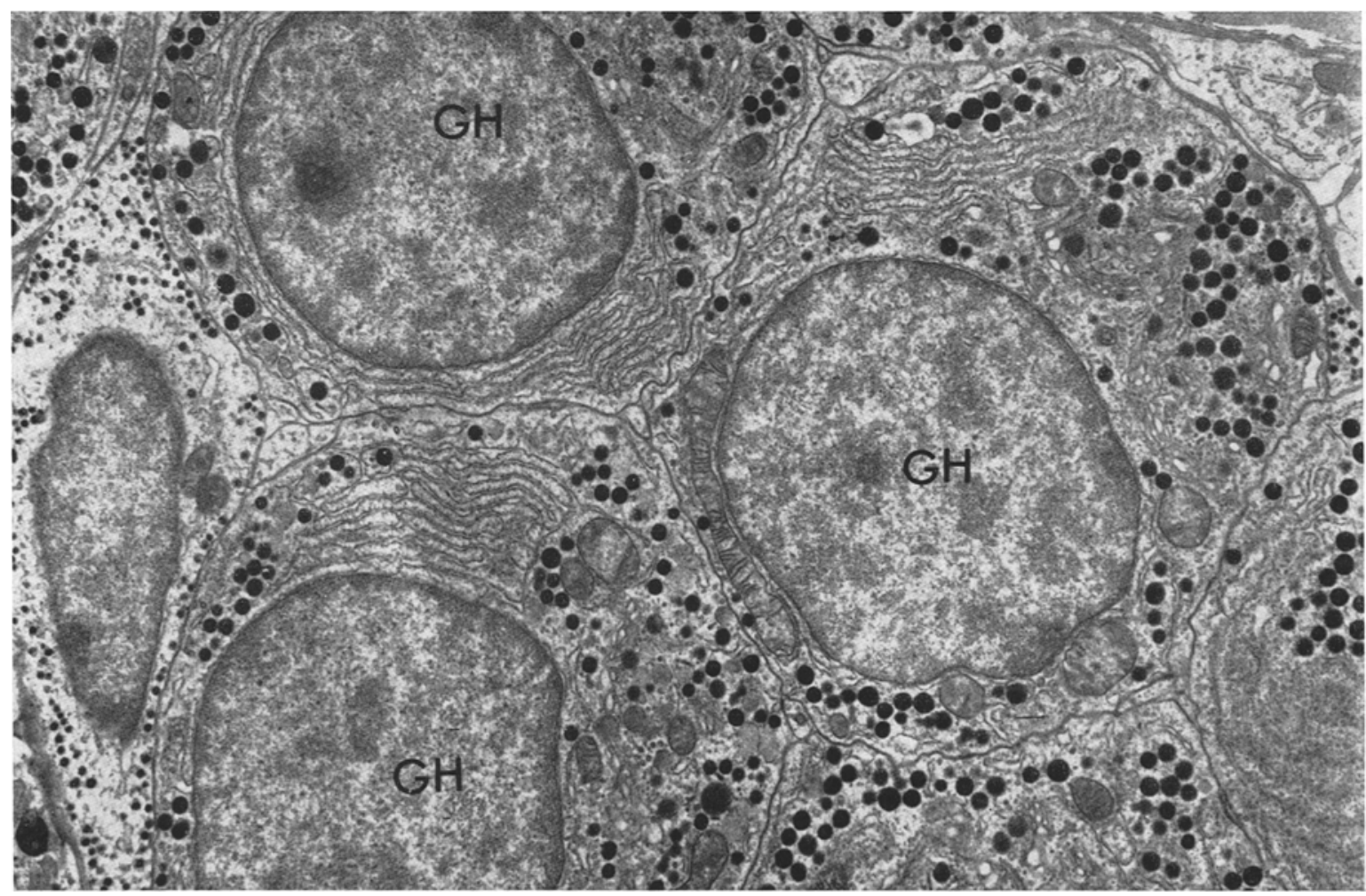

Fig. 12. Electron micrograph of the adenohypophysis of a C57BL mouse. GH cells (GH) are seen. $\times 6000$ 
in the pancreatic islets. On the other hand, insular A cells are encountered far less frequently in KK mice therefore an abundance of glucagon are not likely to occur in KK mice.

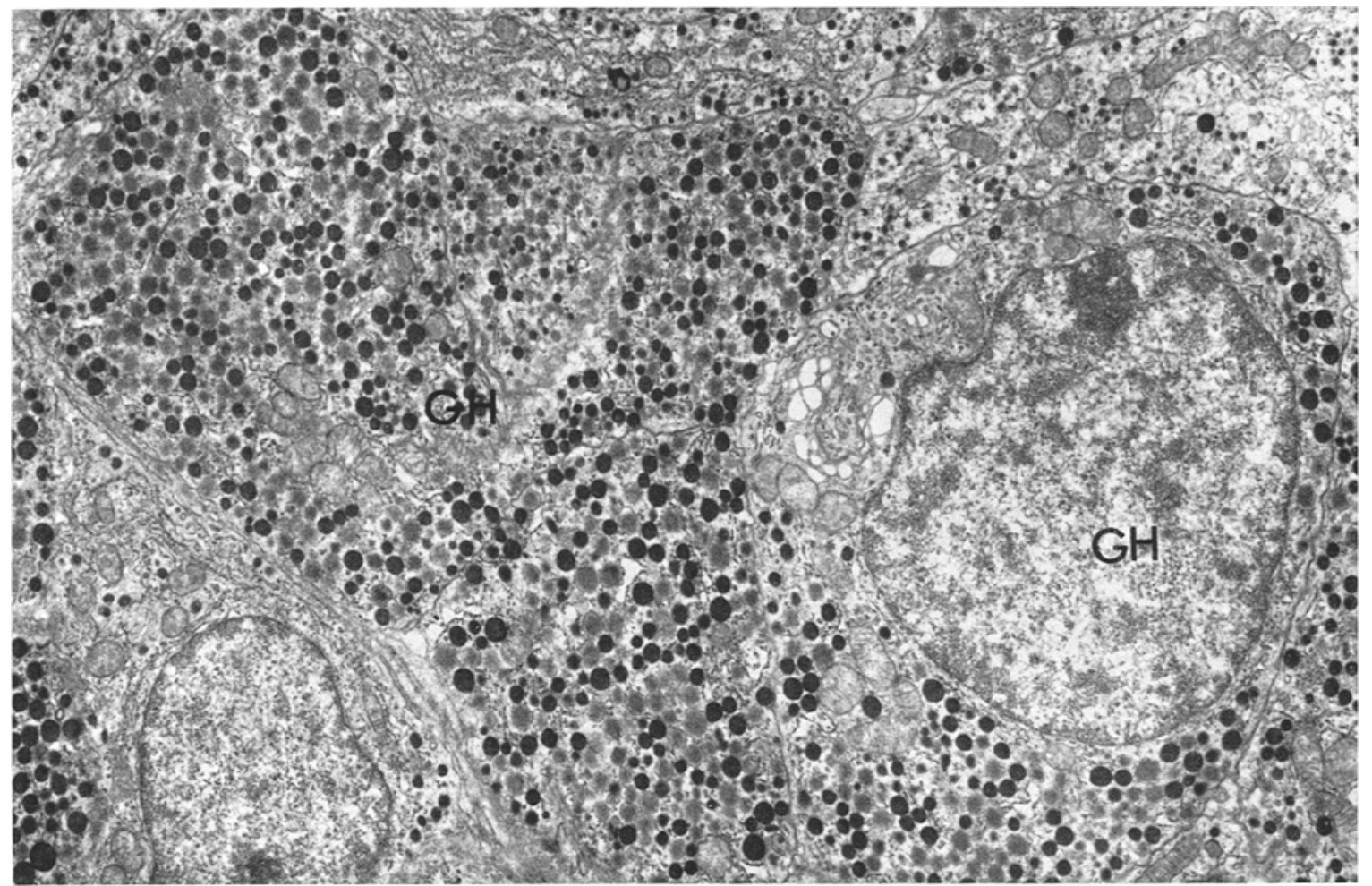

Fig. 13. Electron micrograph of the adenohypophysis of a KK mouse. Secretory granules of the GH cell (GH) are more abundant than in Fig. 12 . $\times 6000$

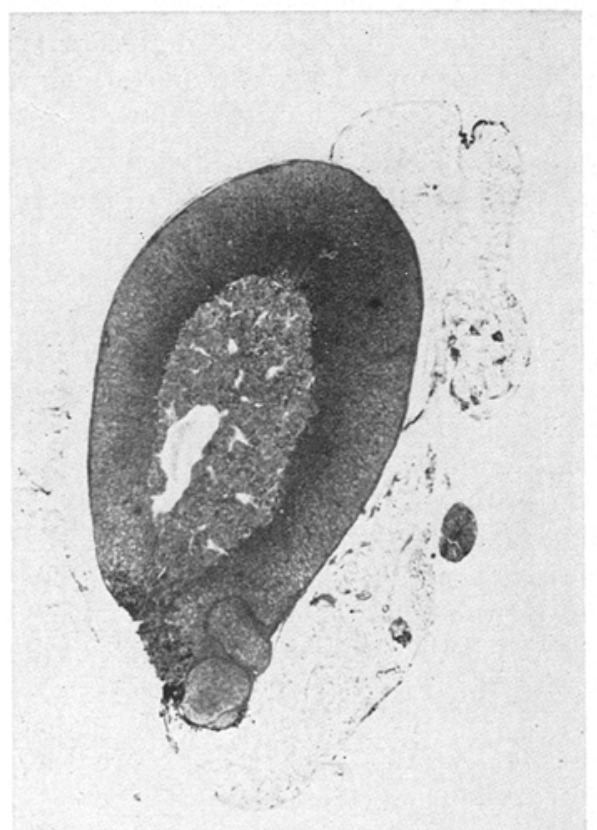

Fig. 14. An adrenal gland of a C57BL male aged 4 months. Ciaccio fixation, H-E stain. $\times 40$

than in control mice. Accordingly, even if the hypertrophy and hyperplasia of the islets are taken into consideration, a numerical increase of $\mathrm{A}$ cells and

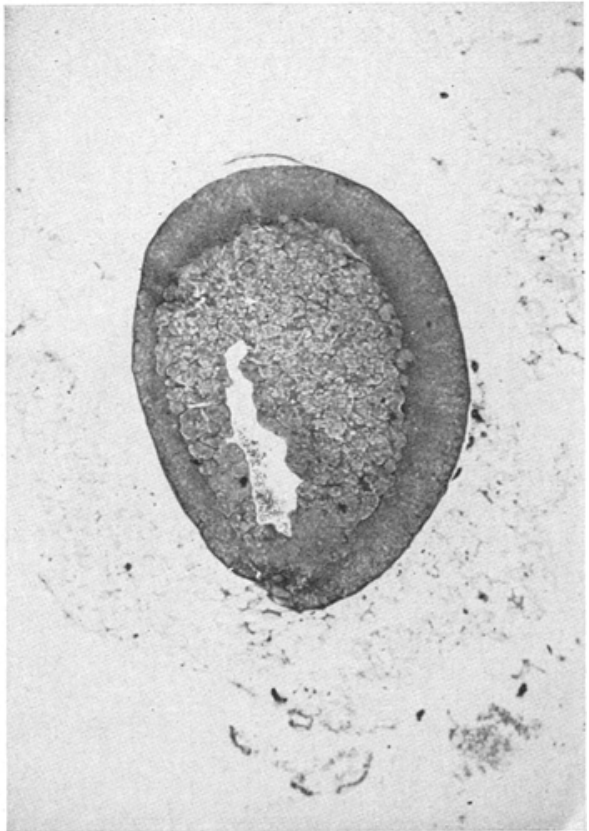

Fig. 15. An adrenal gland of a $K K$ male aged 4 months Cortical layer is markedly thinner than in Fig. 14. Ciaccio fixation, H-E stain. $\times 40$

The results of enzymorphological studies may be interpreted in conformity with biochemical and histological data. For the details of discussion, our 
previous paper (NAKaMURA and YAMADA, 1963) should be referred to.

By electrophoretic and morphological analysis, the anterior pituitaries of KK mice have been shown to

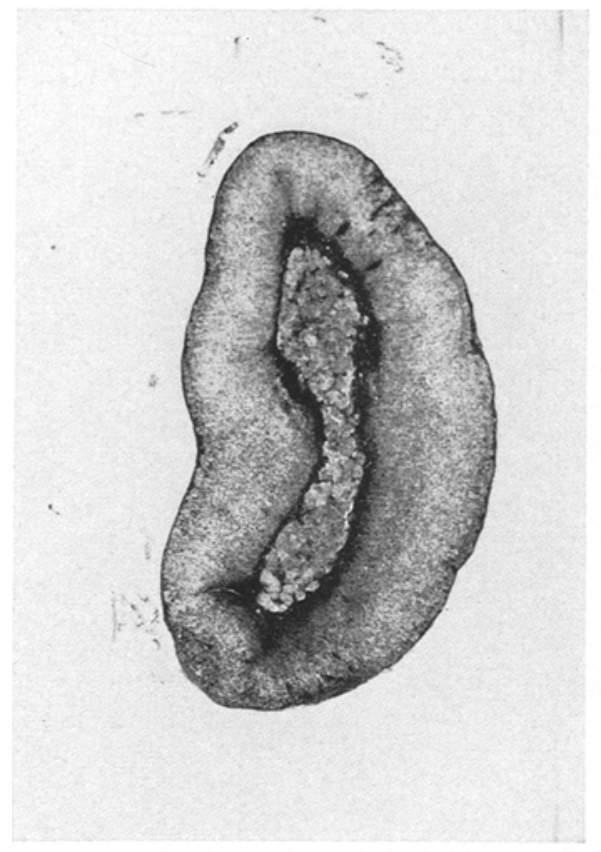

Fig. 16. An adrenal gland of a C57BL female aged 4 months. Ciaccio fixation, H-E stain. $\times 40$

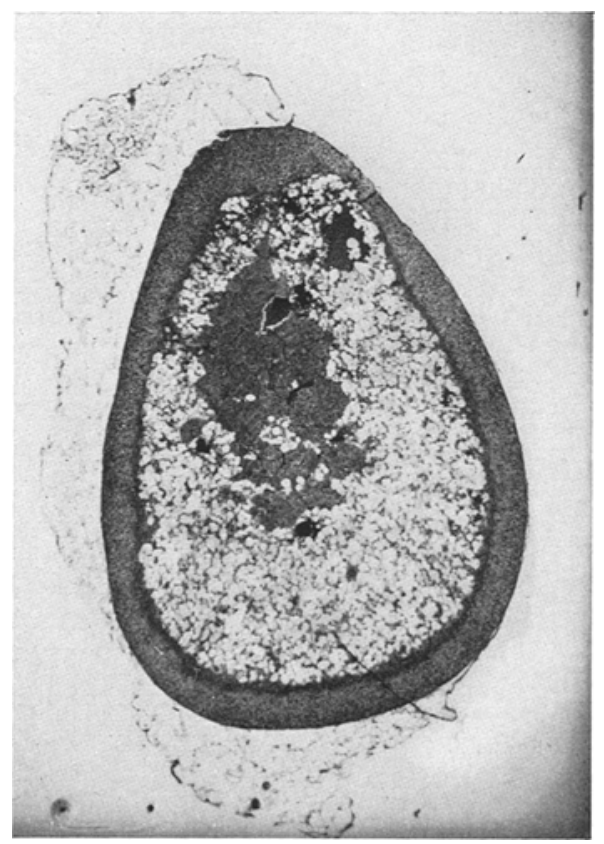

Fig. 17. An adrenal gland of a KK female aged 3 months. Cortical layer is characterized by narrow zonae glomerulosa and fasciculata and by a vacuolized zona reticularis. Ciaccio fixation, H-E stain. $\times 40$

have greater storage of growth hormone than those of control mice. However, on the basis of our data it is impossible to conclude whether the elevated storage of the hormone is due to an accelerated synthesis or to a lowered release of the hormone.

In the livers of KK mice, a scantiness of glycogen

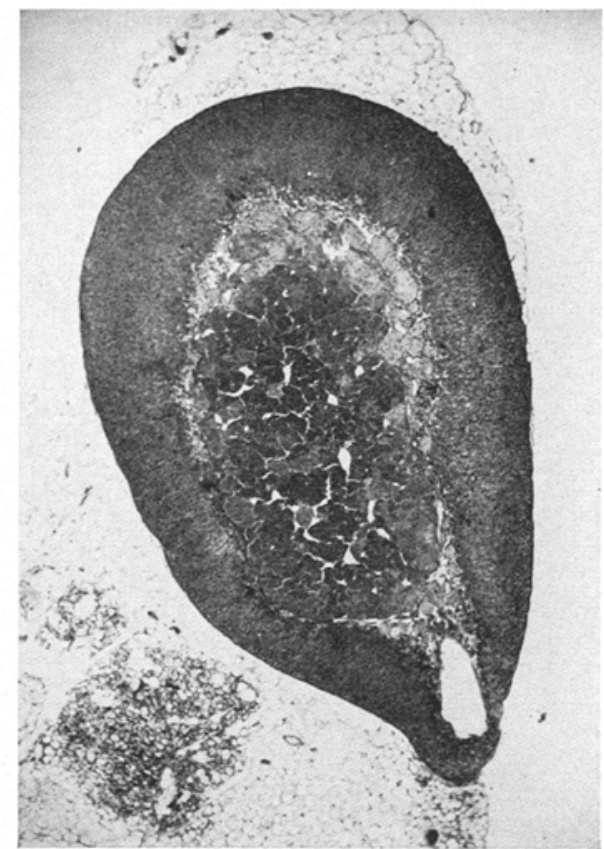

Fig. 18. An adrenal gland of a KK multipara female. In the deeper cortex, large degenerative masses are seen, Ciaccio fixation, II-E stain. $\times 40$

and deposition of lipid were observed. These alterations may be the result of elevated glycogenolysis and abundance of serum NEFA content, which was confirmed in KK mice by TstchIDA (1966).

The adrenals of KK mice show striking histological changes; their significance however, remains to be elarified.

Finally, the following point deserves comment: although we have presumed that there are factors responsible for the diabetic state of $\mathrm{KK}$ mice, we have not discussed what the factors might be. Recent work of Tsuchida seems to throw some light on this point. According to him, suppressed carbohydrate metabolism in peripheral tissues, accelerated glycogenolysis in the liver and excessive mobilization of NEFA from adipose tissues, as observed in KK mice, may be responsible for the diabetio state of KK mice. Complete resolution of this problem, however, will require further study.

\section{References}

Barrnett, R., R. Marshall and A. Semigmax: Histochemical demonstration of insulin in the islet of Langerhans. Endocrinology 57, 419-438 (1955).

Best, C., C. Jefroot and D. Scott: Insulin in tissue other than the pancreas. Amer. J. Physiol. 100, 285$295(1932)$. 
Biflschowsky, M., and F. Biflschowsky: The New Zealand strain of obese mice. Their response to stilboestrol and to insulin. Aust. J. exp. Biol. med. Sci. 34, 181-198 (1956).

Bjorkmax, N., C. Heicerström and B. Hellman: The ultrastructure of the islets of Langerhans in normal and obese-hyperglycemic mice. Z. Zellforsch., 58, 803-819 (1963).

Elftman, H.: A chrom-alum fixative for the pituitary. Stain Technol. 32, 25-28 (1957).

Gomori, G.: The distribution of phosphatase in normal organs and tissues. J. cell. comp. Physiol. 17, 71-83 (1941).

- Observations with differential stains on human islet of Langerhans. Amer. J. Path. 17, 395-406 (1941).

- An improved histochemical technic for acid phosphatase. Stain Technol. 25, 81, (1950).

Heucerström, C., and B. Hercimav : The islets of Langerhans in yellow obese mice. Metabolism 12, 527-536 (1963).

Jones, E.: Spontaneous hyperplasia of the pancreatic islets associated with glucosuria in hybrid mice. The Structure and Metabolism of the Pancreatic Islets, edited by Brolin S.E., B. Hellman and H. KNuTson, Oxford, Pergamon Press, pp. 189-193, 1964.

Kondo, K., K. Nozawa, T. Tomida and K. EzaKI: Inbred strains resulting from Japanese mice. Bull. exp. Animals 6, 107-112 (1957).

Lazarow, A., C. Batere and A. Lindarr: Protein synthesis in islet tissue. The Structure and Metabolism of the Pancreatic Islets, edited by BrouIn, S.E., B. Hellman and H. Knutson. Oxford, Pergamon Press, pp. 203-221, 1964.

LAzARUS, S.: Demonstration of glucose-6-phosphatase in mammalian pancreas. Proc. Soc. exp. Biol. 101, 819 $822(1959)$

LeWIS, U.J., E.V.CheEver and W.P. VANDERLAAN: Studies on the growth hormone of normal and dwarf mice. Endocrinology 76, 210-215 (1965).

Like, A., J. Stemene E. Jones and G. CahmL: Pancreatic studies in mice with spontaneous diabetes. Amer. J. Path. 46, 621-644 (1965).

Mafda, T., T. Fujwwara and K. Hironari: Histochemical demonstration of zinc. Bull. Kobe Med. College 5, 97-99 (1954).

Nakamura, M.: A diabetic strain of the mouse. Proc. Japan. Acad. 38, 348-352 (1962).
- Cytological and histological studies on the pancreatic islets of a diabetic strain of the mouse. Z. Zellforsch.65, $340-349(1965)$.

- Estimation of adenohypophyseal growth hormone content in the diabetic " $\mathrm{KK}$ " mouse strain by acrylamide gel electrophoresis. Proc. Japan. Acad. 42, 512516 (1966).

-, and K. YAMAda, JR.: A further study of the diabetic (KK) strain of the mouse. $\mathrm{F}_{1}$ and $\mathrm{F}_{2}$ offsprings of the cross between KK and C57BL mice. Proc. Japan. Acad. 39, 489-493 (1963).

- - Enzymorphological studies on the pancreatic islets of a diabetic (KK) strain of the mouse. Z. Zellforsch. 66, 396-404 (1965).

OGITA, Z.: Disc electrophoresis. Metabolism and Disease $2,419-435$ (1965).

PAdykuLA, H., and E. Herman: Factors affecting activity of adenosinetriphosphatase and other phosphatases as measured by histochemical techniques. J. Histochem. Cytochem. 3, 161-169 (1955a).

- - Specificity of histochemical method for adenosinetriphosphatase. J. Histochem. Cytochem. 3, 170-195 $(1955 \mathrm{~b})$.

PaLAde, G.: A study of fixation for electron microscopy. J. exp. Med. 95, 285-298 (1952).

TSUCHIDA, I. : Studies on the mechanism of hyperglycemia and obesity in KK strain of the mice. Japan Diabetic Soc. 9, 67-84 (1966).

WACHSTEIN, M. : Histochemical staining reactions of the normally functioning and abnormal kidney. J. Histochem. Cytochem. 3, 246-270 (1956).

Wrenshall, G., S. Andrus and J. Mayer: High levels of pancreatic insulin coexistent with hyperglycemia and degranulation of beta cells in mice with the hereditary obese-hyperglycemic syndrome. Endocrinology $56,335-340$ (1954).

Yamada, K., JR.: The chemical cytology of the mouse parathyroid gland. Z. Zellforsch. 65, 805-813 (1965).

- M. NAKamura and K. Yamashita: Light and electron microscopic studies on the adenohypophysis of a Diabetic (KK) strain of the mouse. In press (1966).

Mttsuo Nakamura, M.D.

Department of Anatomy

Nagoya University School of Medicine Japan. 